British Section of the Society of Protozoologists

Ar the first meeting of the newly formed British Society for Parasitology, which was held at Cambridge during April 3-5, twenty-six protozoologists met to establish a British Section of the Society of Protozoologists. The first meeting of the Section will be held in the Department of Zoology, University College, London, on October 20. All those who are interested in Protozoa are invited to attend. The temporary administrative committee consists of: Mrs. K. M. G. Adam, Department of Zoology, University of Edinburgh; R. J. Cole, Department of Zoology, King's College, London; K. Vickerman, Department of Zoology, University College, London, from whom further information can be obtained.

The Institution of Mining and Metallurgy: Awards

THE following awards have been made by the Institution of Mining and Metallurgy: The Gold Medal of the Institution for 1961, to Prof. F. A. Forward, in recognition of his contributions to the development of metallurgical processes, particularly that of pressure leaching; Honorary Membership of the Institution, conferred on Prof. W. R. Jones, pastpresident, in recognition of his distinguished services to the science of economic geology and to the Institution; 'The Consolidated Gold Fields of South Africa Limited' Gold Medal for the session 1960-61, to K. C. G. Heath, for his paper entitled "Mining and Metallurgical Operations at Rhodesia Broken Hill-Past, Present and Future" (Trans. Inst. Min. Metal., 70); 'The Consolidated Gold Fields of South Africa, Limited' Premium of Forty Guineas for the session 1960-61, to Dr. J. A. E. Allum, for his paper entitled "Photogeological Interpretation of Areas of Regional Metamorphism" (Trans. Inst. Min. Metal., 70).

\section{Lederle Medical Faculty Awards}

The Lederle Laboratories Division of the American Cyanamid Company is making available a number of medical faculty awards which will begin with the academic year 1963-64. These awards are intended only for individuals who share in all departmental responsibilities, particularly in the teaching of undergraduate medical students. They are not intended to be research fellowships, or for the support of individuals whose only or major function and interest is the conduct or supervision of research activities. They are also not intended for assistance of research departments or divisions of postgraduate medical schools, but are primarily for assisting medical schools in providing for their major clinical disciplines individuals who, having demonstrated interest and ability in teaching and researeh, will devote their major efforts to the teaching of clinical medicine with the view of integrating the knowledge and principles of the biological sciences, as applied to man. Further information can be obtained from Lederle Medical Faculty Awards, Office of the Secretary, Pearl River, New York.

\section{Spectroscopy in the Metallurgical Industry}

A symposium on "Spectroscopy in the Metallurgical Industry", arranged by the Spectroscopy Group of the Institute of Physics and the Physical Society in collaboration with the British Non. Ferrous Metals Research Association and the British Iron and Steel Research Association, will be held in Buxton, Derbyshire, during July 5-6. The programme will include: $\mathrm{X}$-ray fluorescence analysis of copper alloys; X-ray fluorescence analysis in metallurgical research; mass spectroscopy; spectrographic control of nickel alloy production; control analysis in a steel works; control analysis for stainless steel production; analysis of high silicon steels with a vacuum spectrometer; spectroscopy in the assay of precious metals; spectroscopy in the German metallurgical industry. Further information can be obtained from Dr. L. Bovey, Building 329, Atomic Energy Research Establishment, Harwell, Didcot, Berks.

\section{Announcements}

THE twelfth world poultry science congress will be held in Sydney during August 13-18. Further information can be obtained from the Ministry of Agriculture, Fisheries and Food, Whitehall Place, London, S.W.1.

THE thirteenth session of the International Commission for Uniform Methods of Sugar Analysis will be held in Hamburg during August 26-31. Further information can be obtained from Dr. D. Gross, Tate and Lyle Research Laboratories, Keston, Kent.

THE International Federation of Information Processing Societies Congress, 1962, is to be held in Munich during August 27-September 1. An exhibition of computers and other information processing will be held during the congress. Further information can be obtained from Dr. A. P. Speiser, IBM Research Laboratory, Zurichstrasse 108, Adliswil-Zurich.

THE second international congress of radiation research, sponsored by the International Committee for Organizing Congresses of Radiation Research and the Association for Radiation Research, will be held in Harrogate during August 5-11. Further information can be obtained from Dr. Alma Howard, Mount Vernon Hospital, Northwood, Middlesex.

THE 1962 Summer School in Infra-red Spectroscopy, organized by Unicam Instruments, Ltd., will be held in Cambridge during July 15-28. Residence will be in Gonville and Caius College, and practical tuition in sample handling and interpretation will be given in the laboratory of Unicam Instruments, Ltd., at the newly opened Scientific Centre. Further information can be obtained from Mr. D. E. Sheppard, Unicam Instruments, Ltd., York Street, Cambridge.

AN interdisciplinary conference on "Electromagnetic Scattering", sponsored by the Division of Colloid Science and Surface Chemistry of the American Chemical Society and the Office of Aerospace Research of the United States Air Force, will be held in Potsdam, New York, during August 13-15. The programme will include the following sessions: scattering by spherical particles; scattering by nonspherical particles; scattering by charged species in solution; interactions in solids and liquids as determined by electromagnetic scattering; multiple and incoherent scattering. Further information can be obtained from Dr. Milton Kerker, Clarkson College of Technology, Potsdam, New York.

Erratum. In the article "Hazards of Dust", appearing on p. 244 of the April 21 issue of Nature, Prof. R. C. Browne reviews The Relation between Pneumoconiosis and Environmental Conditions: an Analysis of the Results of the First Series of X-ray Surveys in the National Coal Board's Pneumoconiosis Field Research. The authors of this report are D. Hicks, J. W. J. Fay, J. R. Ashford and S. Rae, and not the two latter only as printed in the review. 